\title{
Utilization of RFID data to evaluate characteristics of private car commuters in Middle East Technical University campus
}

\author{
Orta Doğu Teknik Üniversitesi yerleşkesindeki düzenli özel araç \\ kullananların karakteristiklerinin değerlendirilmesinde RFID verisi \\ kullanımı
}

\author{
Oruç ALTINTAŞI $1^{*}$, Hediye TÜYDEŞ YAMAN ${ }^{1}$ \\ 1Department of Civil Engineering, Faculty of Engineering, Middle East Technical University, Ankara, Turkey. \\ aoruc@metu.edu.tr, htuydes@metu.edu.tr
}

\begin{abstract}
Analyzing travel behavior of Middle East Technical University (METU) campus users via traditional survey approach requires great effort. However, using Radio Frequency IDentification (RFID) system installed at all the campus entry gates provided a cheaper and an effective approach to determine basic characteristics of the campus private car commuters. The RFID data combined with traveler details enabled the study of the arrival and departure car-based commute behavior of academic personnel, administrative personnel and students, separately. The results revealed that campus car-based travel demand is mainly active between 07:00 to 22:00. While the majority of the private car commuters arrive during 08:00-09:00, the evening peak is distributed over a much longer period from 15:00 to 19:00. Administrative personnel have sharper evening departures between 17:00-18:00, while academic ones show a more scattered pattern lasting longer. Cartraveler students mostly arrive later during 09:00-10:00 and start leaving the campus as early as 15:00 lasting until late evenings. Stay time of vehicles on campus revealed that $43 \%$ of all trips to campus lasted less than 15 minutes, especially during morning and evening peaks, suggesting that a high number of RFID card holders pass through the campus, possibly for pick-ups or drop-offs. A small reverse commute pattern occurred due to the trips generated by family members of those living in on-campus housing units.
\end{abstract}

Keywords: Commute travel, Travel demand, Travel behavior

\section{Introduction}

Big university campuses may generate a travel demand like a small city, where a strong commute behavior is inevitable. In the case of Middle East Technical University (METU) campus in Ankara, Turkey, we see a total population over 30000 people, and 21000 of them are students: omitting the approximately 6000 students living in dormitories, 15000 students regularly commute; while only 2000 of them hold stickers for private car usage, the remaining mainly use public transit and paratransit services in accessing to the campus. Out of 4300 people who work as faculty and administrative personnel at METU, only 350 of them live in on-campus housing units; among the noncampus dwellers, a significant portion of the administrative personnel use commute buses provided by the university, and most of the academics use private car. The research and development park on campus, called Technopolis, has a population of 3000 , and is another region triggering commute travel. Besides, the campus also has K-12 educational units

\begin{abstract}
Öz
Orta Doğu Teknik Üniversitesi (ODTÜ) kampüs kullanıcılarının seyahat davranıșını geleneksel anket yaklașımı ile analiz etmek büyük çaba gerektirmektedir. Ancak, tüm kampüs giriş kapılarında kurulu radyo frekansı ile tanımlama sistemi (RFID) sistemi, yerleșkedeki düzenli özel araç kullanıcılarının temel özelliklerinin belirlemek için daha ucuz ve etkin bir yaklaşımın geliştirilmesine imkan sağlamaktadır. RFID verisinin kullanıcı bilgileriyle birlikte incelenmesi, akademik personel, idari personel ve öğrencilerin yolculuklardaki geliş ve gidiş davranıșlarının ayrı ayrı çalıșılmasına olanak sağlamıștır. Sonuçlar, özel araç tabanlı yolculuk talebinin 07.00-22.00 arasında aktif olduğu göstermektedir. Düzenli yolculuk yapanların çoğunluğu 08.00-09.00 arasında yerleșkeye giriș yaparken, akșam zirve saati 15.00'dan 19.00'a kadar daha uzun periyoda dağılmıştır. İdari personel akșamları belirgin bir șekilde 17.00-18.00 arasında çıkarken akademik personel araç çıkışı daha dağınık ve uzun süren bir profil göstermektedir. Özel araç kullanan öğrenciler çoğunlukla 09.00-10.00 saatleri arasında gelmekte ve çıkışları 15.00'dan itibaren gece geç saatlere kadar sürmektedir. Araçların yerleșke içinde kalma süreleri, özellikle sabah ve akșam zirve saatler boyunca, \%43'ünün 15 dakikadan daha az kaldığını göstermektedir; bu da birçok tașıt pulu sahibinin büyük olasılıkla eş/çocuk alma/bırakma için yerleșkeden geçtiğini düşündürmektedir. Zirve saatlerde tespit edilen ters yönlü düzenli bir yolculuk akımı, kampüs içinde yașayanların aile bireyleri tarafindan gerçekleștirilen yolculuklardan kaynaklanmaktadır.

Anahtar kelimeler: Düzenli yolculuklar, Yolculuk talebi, Yolculuk davranıșı
\end{abstract}

(a nursery, an elementary and a high school) for the children of campus workers, which contribute to the commute travel behavior, as well.

METU campus originally developed outside the city limits at a distance of approximately $13 \mathrm{~km}$ to the city center. Currently, it is surrounded by the city and access is controlled at 3 main gates (Gate A1, A4 and A7) as shown in Figure 1. The campus is accessible by bus and minibus services operated by the municipality or privately, departing from the city center. However, private car is an ever-increasing commute mode. In order to monitor and control the campus road network usage, Radio Frequency IDentification (RFID) system is installed at the main entry gates; RFID stickers are granted to faculty and administrative personnel directly, and to students in limited number. Additionally, RFID gate is in use to control the traffic from Technopolis to campus (see Figure 1).

The determination of the travel behavior of METU campus users requires traditional survey approaches, which would 
need a big amount of resources. However, the integration of a series of data from different campus data sources (RFID and video recordings) provided a cheaper and an effective approach to determine the basic characteristics of the campus commute behavior, which is the main focus of this study.

The layout of this paper is as follows: After a brief review of literature on commute travel studies in university campuses in Section 2, the RFID data analysis approach is summarized in Section 3 , followed by the major commute behavior findings summarized in Section 4 and followed by the discussion and conclusions in the last section.

\section{Literature review}

The analysis of the travel behavior of campus users has been the focus of many studies so far. Zhou [1] studied the commute behaviors of university students in Los Angeles. He stated that improvement of multimodal transportation system and discounts in public transit may greatly change the travel behavior of students. Miralles-Guasch and Domene [2] determined the travel pattern and transportation challenges of university travelers in Barcelona through an online survey, where the lack of adequate infrastructure, the marginal role of walking and cycling and longer time involved in using public transport were detected as the main barriers to shift from private car to non-motorized modes. Akar et al. [3] also examined the travel patterns of the campus community at Ohio State University. The results demonstrated that students were more likely to travel by alternative modes compared to faculty members. Limanond et al. [4] studied the travel behavior of 130 students who live on campus in a rural university, and found that males and females had similar travel pattern; students owning a car preferred driving and non-car owners preferred riding with a friend or on a bus. Another study conducted by Gilhooly and Low [5] investigated the primary school travel behavior in Midlothian, Scotland, via survey of 1008 primary school children and 776 parents. They stated that travel behavior was significantly influenced by age and the distance from school. As an evaluation of parking management on Beijing University of Aeronautics and Astronautics, China, Huayan et al. [6] obtained inflow and outflow of vehicles during the day and calculated the average parking stay time of vehicles and drew conclusions about the travel behavior of university travelers.

There has been no campus travel study that took advantage of data from new technologies, such as RFID, mostly because, such data does not include traditional travel demand data; but, it is mainly being used to develop parking management policies for university campuses. It enables identification of the vehicle movements, records the vehicle data, analyzes the traffic pattern different time of a day, manages staffing peak hour traffic and relieves congestion [7]. Arizona State University, in USA, installed RFID system to all parking lots to implement parking management strategies, such as more parking charges for students [8]. Wayne State University, in USA, installed RFID system to the campus parking lot locations to implement parking charges for different commute travelers [9]. University of Wisconsin, in Madison, in USA, RFID system was installed to the gate activation in parking ramps to investigate the environmental impact the RFID gate project has on starting/stopping at the gate entrance. The results showed a significant savings in fuel due to reduction in start, stop and idle time [10]. Furthermore, Portland State University, in USA, RFID system was used to track their employees who sign up for a bike commute incentives program [11].

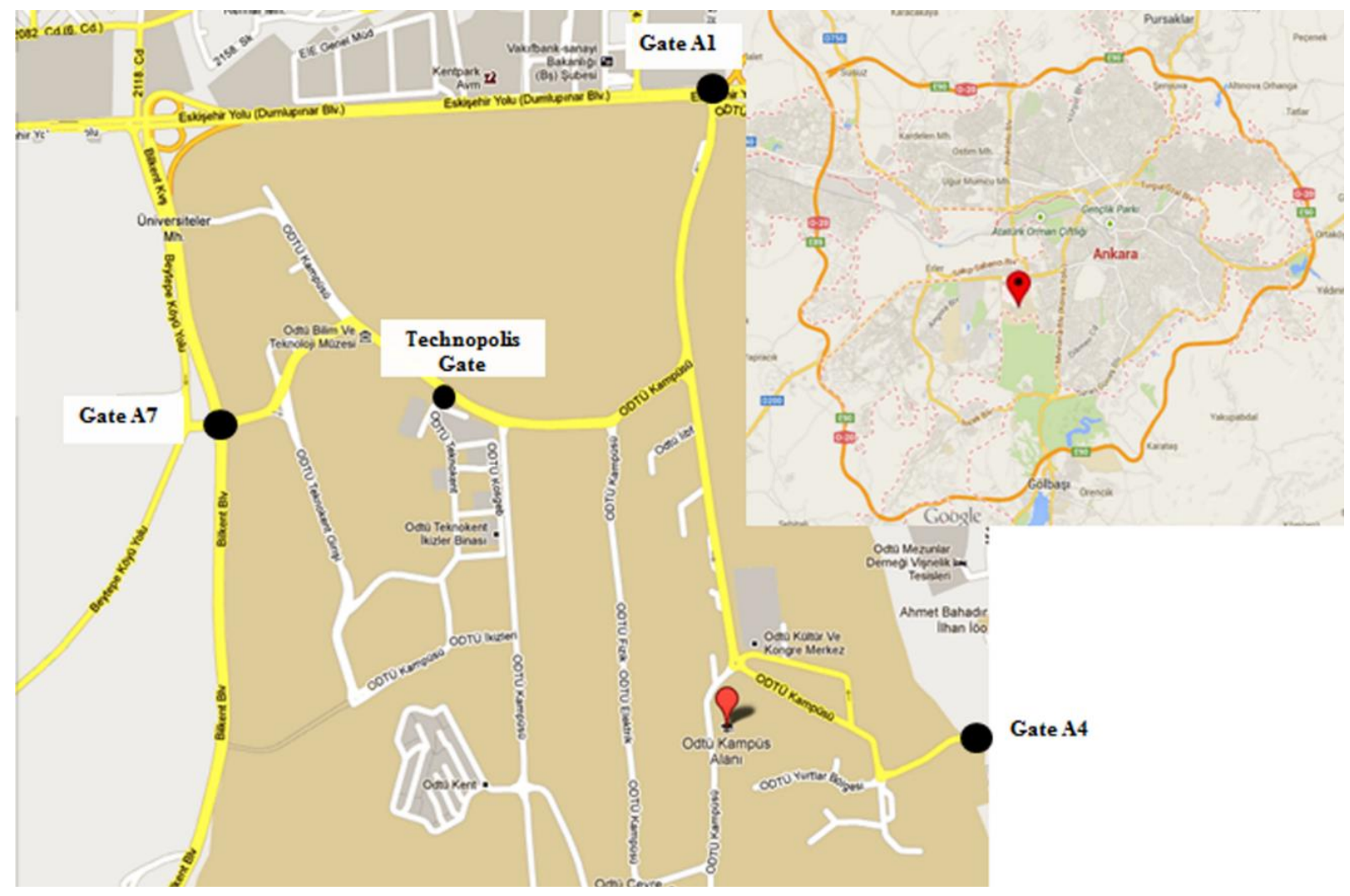

Figure 1: The location and the layout of METU Campus. 


\section{Utilization of RFID data to evaluate commute behavior}

The RFID data can be further analyzed to reveal travel pattern behavior, if supported with additional counts and/or data processing. Nevertheless, the location of the RFID readers in a region would inherently shape the capability and limits of such evaluations; if a region has limited entry points which are fully RFID controlled creating a closed network like METU campus, it would provide a very rich data that could portray campus access behaviors of the commuters, but it would not reveal much about their destinations or route choice within the campus. If not, RFID data would reveal information about the behavior of users enrolled in the system only, which means it would be a sample of the whole commuter; in such cases, it is important to consider the enrollment conditions, to get an idea about the randomness of the sampling. While evaluating the benefits of RFID data usage, it should be kept in mind that traditional commute behavior studies rely on sampling in their surveys, which may include some sources of bias, themselves. But, RFID data-based evaluations would present "revealed" behaviors as opposed to "stated" ones in the survey-based approaches. Thus, it is impossible to capture everything about commute trips via either survey-based or RFID-based approaches, and it is important to understand the limitations and sources of bias in the natures of the different approaches.

In the current study, the existence of RFID control system for private car users at all campus access gates made it possible to capture the mobility of all the car-based commuters. As the RIFD sticker includes the license plate number, sticker type, and the entry and exit location (see Table 1), it was possible to obtain campus entry and exit information for all the movements of different commuter types (academic and administrative personnel, students, Technopolis workers, and parents of elementary-high school children). Tabulation of the entry and exit movements hourly (or in 15-minute intervals, if desired) easily provides the daily campus profiles.

Further processing the RFID data for every unique license plate enabled the detection of all the recorded movements of the vehicles, leading to matching of entry-exit pattern that would define a "trip" (see Table 1). Even though it was not needed in the campus daily profile calculation, the minor gate controlling the access to/from Technopolis is also considered as a gate in the trip detections so that the trips destined to and originating from Technopolis region could be identified separately. Moreover, calculation of a "stay time" for a trip, which is simply the difference of the exit and entry times, sheds more light on the commuter behavior of the campus user. As the trips and their stay times can be time-stamped, it is possible to see the change in the stay times in a day.

Normally, trips detected from an RFID data processing should be regarded as "commute trips" directly; the purpose of the trips must be checked. However, in the case of METU campus RFID data study, it should be noted that METU grants RFID data only to campus commuters, which dismisses any concern on the matter. Secondly, although the majority of the commute trips are "work" trips, which are expected to happen in the morning and in the evening, it is not possible to generalize it for every campus user, as some would be working the late evening and night shifts in different units. Thirdly, it is not possible to know the true origin or destination of these trips from RFID data, yet, the lack of such information does not necessarily endanger the study of basic characteristics of the campus commute behaviors.

RFID data would have some reliability issues, as well. Due to some reading errors, it is possible to miss an entry or an exit of a vehicle, which would leave unmatched recording. However, an unmatched trip can be due to an over-night or late stay in the campus, or leaving the car in the campus and having a return trip with another mode for some reason. Similarly, an exit with a missing entry could indicate a car trip from a previous day.

\section{METU commute traveler characteristics}

To study the commute characteristics, a whole week RFID data from Nov 21-25, 2011 was processed. To give an idea of the scale, the statistics from Wednesday of the control week is summarized in Table 2 . The analysis result showed that $91 \%$ of the vehicles tracked by RFID systems were private cars (the remaining was the bus, taxi and minibuses serving the campus). It shows that the majority of the motorized vehicle demand in the METU campus was due to the private car access. To validate the results from RFID data, video recordings of the security cameras at the entry gates were processed for another Wednesday, which showed that there were almost 3000 additional vehicle entries, some of which can be due to daily fluctuations but the majority is due to the vehicles visiting the campus. In the video recordings, the difference between the total entries (15280) and exits (14828) was very small suggesting that the majority of the vehicles did not stay overnight. However, this difference in the RFID data was 5074 movements due to significantly lower number of recorded exits. Further calculation of the entry-to-exit ratios for each gate from RFID and video data showed that the majority of this difference was caused by a reading error in the exit lanes of the gate A1 (see Table 2). Exit behavior in this study is underestimated; however, this systematic error happened throughout the whole observation day and affects all the cardholder types similarly. Thus, it does not create any bias on the time of the day or the cardholder type analysis.

\subsection{Campus daily travel profile}

The RFID gate data can simply be used to derive the daily demand profile of METU campus and to detect the peak hours. Daily analyses revealed very small variations between the weekdays in METU campus [12], thus, the average entry and exit profiles is used to illustrate the travel demand profile as shown in Figure 2. Both entry and exit profiles support the existence of the urban commute behavior among the METU campus travelers, where majority lived in the city and arrived METU as their workplace. Only a small reverse commute pattern was observed due to the on-campus housing population. The characteristics of the daily commute profile were as follows:

- A major entry demand was observed between 07:0009:00; during which hourly arrivals reach up to 3000 . Then, the campus entry demand gradually decreased until 11:00; after a small peak around 12:00, entry demand was almost constant at a rate of 1000 vehicles/hour until 18:00, after which it diminished significantly till midnight.

- The exit profile of METU campus showed little activity until 07:00, after which the number of exiting vehicles increased creating the first peak between 08:00-09:00 with 1500 exits. This may be due to i) 
commuting from the family members of personnel residing in the on-campus housing units, and ii) car users doing quick drop-off for a campus user. The second peak was seen at noon (12:00-13:00) with 1200 exits. The majority of the exit demand was scattered over time, starting from 15:00 to 19:00, which revealed the highest volume (over 2300) during 17:00-18:00. After 19:00, the number of exiting vehicles gradually decreased.

\subsection{Commute behavior of different campus travelers}

Availability of the cardholder information in the RFID data revealed more about the commute behaviors of the different campus users. The extensive analysis of the commute behaviors of the academic and administrative personnel and students was provided in [12], which can be summarized as follows, for the sake of continuity:

- Administrative personnel showed a sharper morning arrival (see Figure 3) and evening departure times (see Figure 4), parallel to definitions of their work hours between 08:30-17:30, which is expected as their work schedules are more definite.

- Academic personnel had also a sharp morning arrival peak. A major exit demand was observed during the evening hours, which started from 15:00 and continued until 21:00. The small peak in the exit profile during 08:00-09:00, may very well be the private car users of families of academic personnel residing on campus creating the reverse commute.

- The entry profile of student travelers showed that travel to the campus started to increase after 08:00; a delayed morning peak was seen around 09:0010:00 (see Figure 3). After, entries gradually decrease during the day. The exits of students started from 08:00 and gradually increased throughout the day (see Figure 4). After that, they had again scattered evening peak that start from as early as 15:00 and continue until 20:00.
- $\quad$ Private car usage among Technopolis workers was a major component of the campus car usage. Their movements suggested a much clearer "work" trip purpose with sharper arrival and departure time windows. Their entries started as early as 06:00 and continue until 09:00, after which it dropped significantly (see Figure 3). The second peak during lunch time definitely indicated a strong "lunch trip" demand which showed a typical urban travel demand profile. Lastly, parents of children were active only at 08:00-09:00 and 15:00-16:00.

\subsection{Stay times of private car commuters}

The stay time analysis results in Table 3 of the METU campus users showed that in the overall evaluations, $42.8 \%$ of the trips by the RFID cardholders were "short stay", that is less than 15 minutes. A second major traveler group stayed between 1-5 hours $(22.9 \%$ in a day), which is more like a half workday time. Only $16.1 \%$ had long stays of 5-10 hours suggesting that they may be academic or administrative personnel. The low percentage of the long stays in spite of the large number of personnel may be due to the fact that some of the personnel had multiple trips in and out of the campus.

During the early morning hours (07:00 to 10:00), more than 40 $\%$ of the entering vehicles stayed for a short time, $20-30 \%$ stayed almost the whole work day (5-10 hours), while another major group stayed half a day (1-5hours). The further investigation of the RFID cardholders among these drivers revealed that the major short stays were performed by Technopolis workers (46.0\%). While academic and students had almost same ratio (17.5\%), the parents of the children at the elementary and high school constituted $11.7 \%$.

The short stay ratios were predominant in the evening hours (between 17:00-20:00), exceeding 60\%. The traveler distributions in these short stays were: $35.7 \%$ for Technopolis workers, $28.1 \%$ for academics, $24.0 \%$ for students and $8.2 \%$ for administrative personnel. Only $4.2 \%$ of the total short trips were performed by the parents of the children, which is proportional to the number of stickers provided.

Table 1: Vehicle movements as a result of RFID gate data processing.

\begin{tabular}{cccccccc}
\hline License Plate & Sticker Type & Time 1 & Gate & Entry/Exit & Time 2 & Gate & Entry/Exit \\
\hline 01HJ361 & Academic & $07: 54$ & A1 & Entry & $12: 00$ & A4 & Exit \\
06AC651 & Student & $15: 05$ & A4 & Entry & $19: 49$ & A4 & Exit \\
\hline
\end{tabular}

Table 2: METU campus vehicle activity statistics.

\begin{tabular}{|c|c|c|c|c|c|}
\hline & & \multicolumn{2}{|c|}{$\begin{array}{c}\text { RFID data } \\
\text { Nov } 23,2011 \text { (Wed) } \\
\end{array}$} & \multicolumn{2}{|c|}{$\begin{array}{c}\text { Video data } \\
\text { Oct } 19,2011 \text { (Wed) }\end{array}$} \\
\hline & & All Vehicles & Private Cars & All Vehicles & Private Cars \\
\hline \multirow{3}{*}{ Total } & Entry & 12194 & 11471 & 15280 & 14363 \\
\hline & Exit & 7120 & 6694 & 14828 & 13938 \\
\hline & & 5074 & 4777 & 452 & 425 \\
\hline \multicolumn{6}{|l|}{ All Vehicles } \\
\hline Gate & & \# & Ratio & $\#$ & Ratio \\
\hline \multirow{2}{*}{ A1 } & Entry & 5354 & \multirow{2}{*}{3.61} & 5746 & \multirow{2}{*}{0.94} \\
\hline & Exit & 1482 & & 6066 & \\
\hline \multirow{2}{*}{ A4 } & Entry & 4116 & \multirow{2}{*}{1.16} & 5839 & \multirow{2}{*}{1.01} \\
\hline & Exit & 3562 & & 5777 & \\
\hline \multirow{2}{*}{ A7 } & Entry & 2724 & \multirow{2}{*}{1.31} & 3695 & \multirow{2}{*}{1.24} \\
\hline & Exit & 2076 & & 2985 & \\
\hline
\end{tabular}




\section{Average Daily Travel Demand Profile}

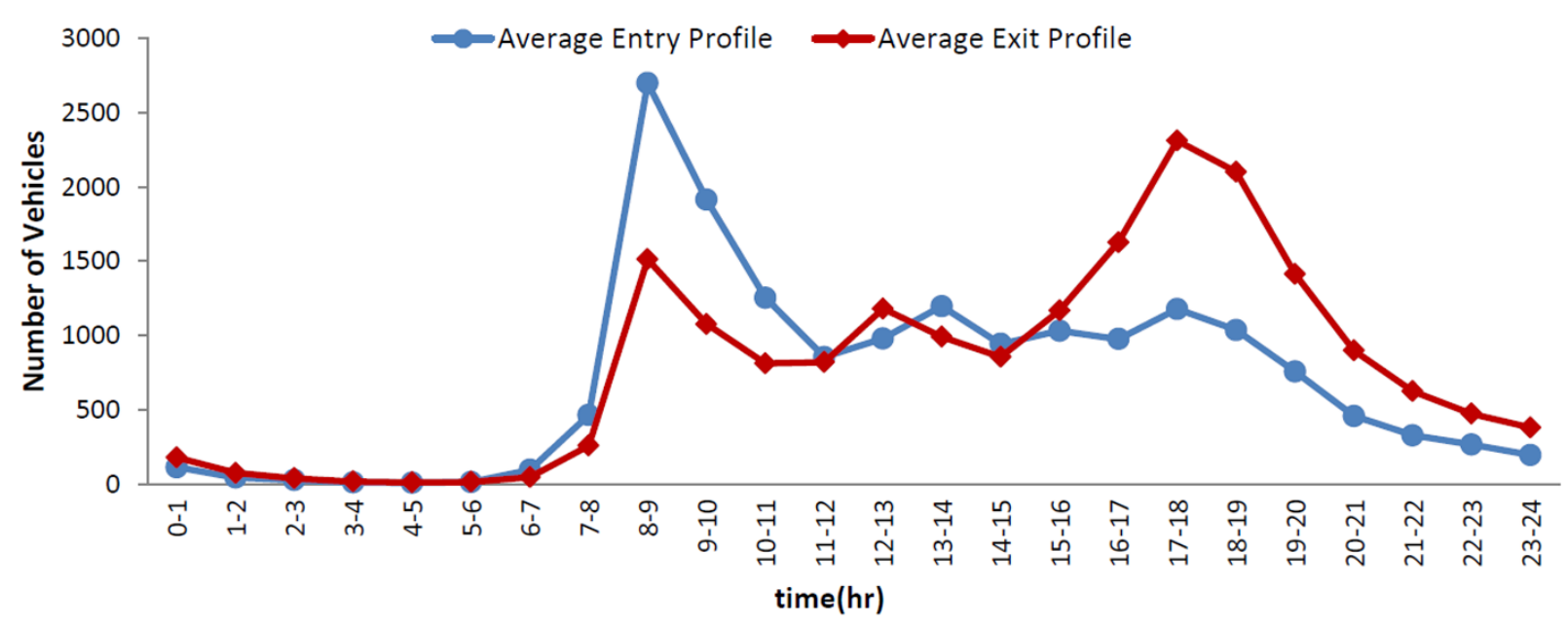

Figure 2: Average daily travel profile of METU campus on 21-25 November 2011.

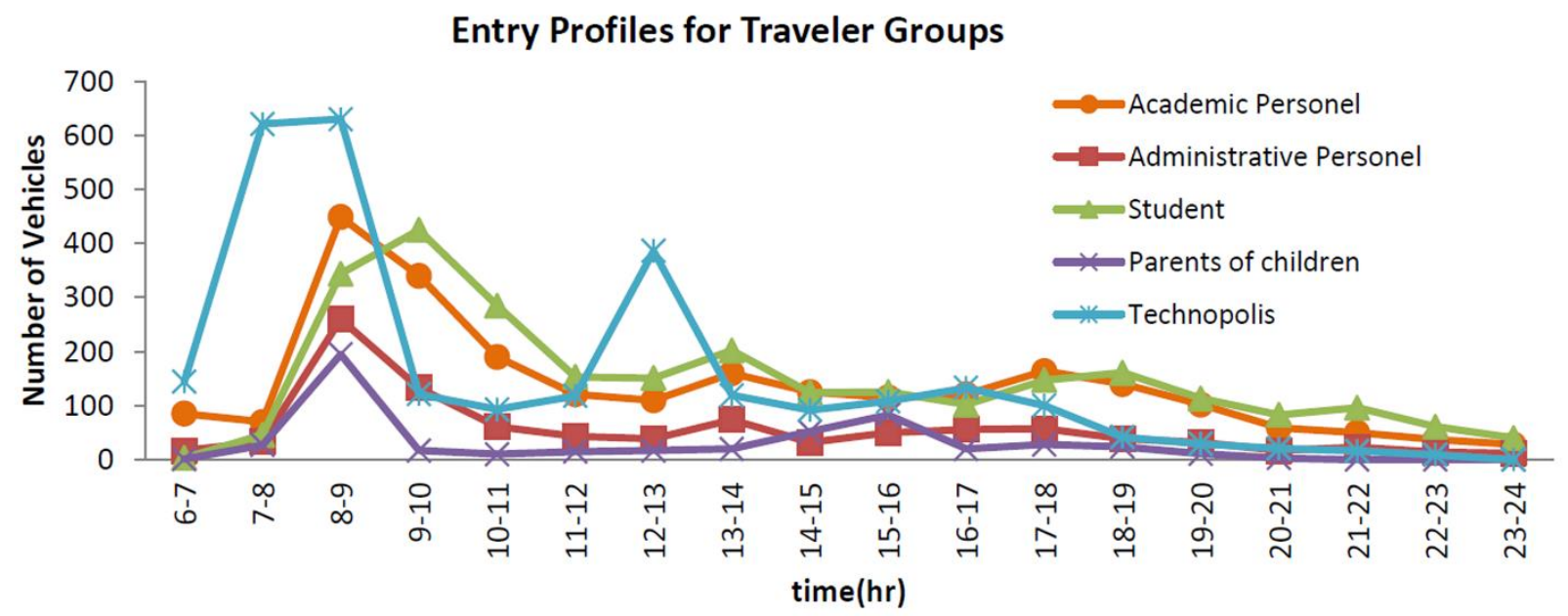

Figure 3: Entry profiles of major traveler groups in a day.

\section{Exit Profiles for Traveler Groups}

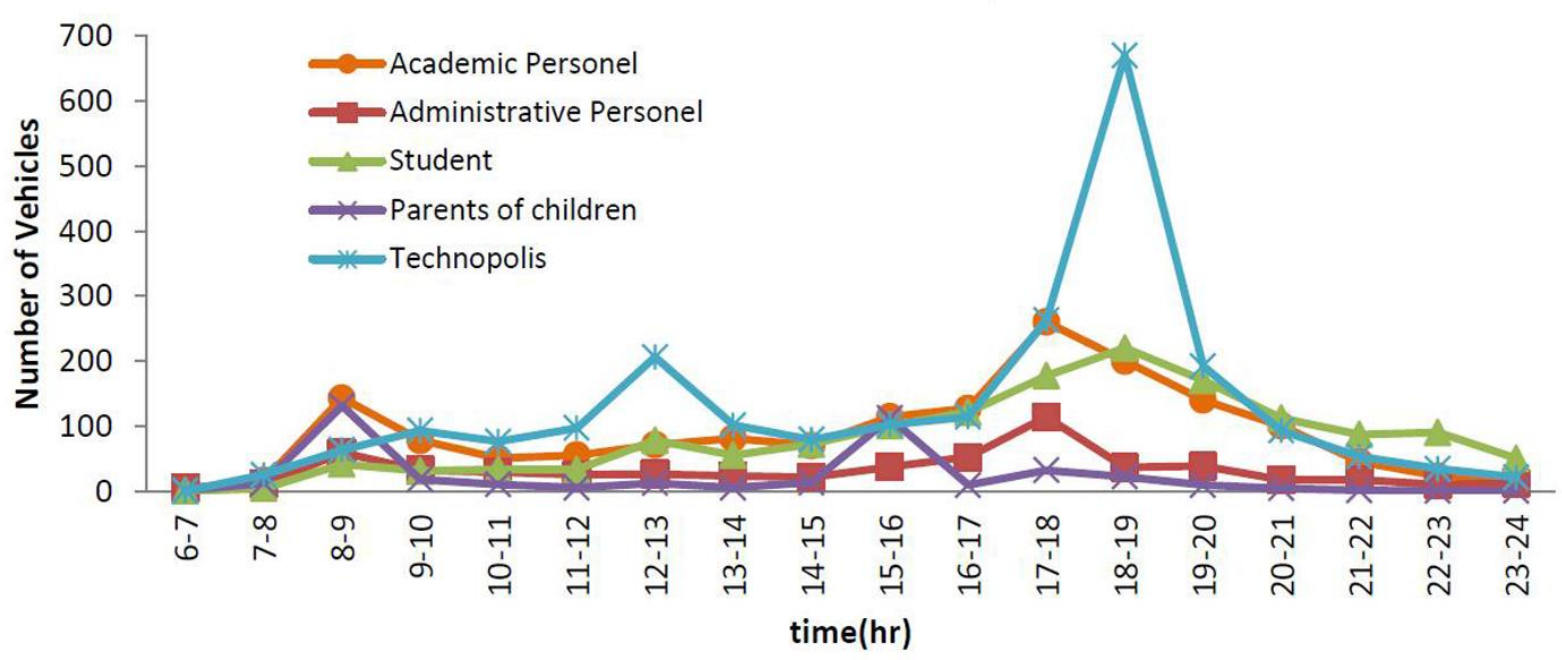

Figure 4: Exit profiles of major traveler groups in a day. 
Table 3: Campus stay time of vehicles by entry time.

\begin{tabular}{|c|c|c|c|c|c|c|c|}
\hline \multirow{2}{*}{ Entry Time } & \multirow{2}{*}{ \# of Trips } & \multicolumn{6}{|c|}{ Stay Time (Nov 23,2011$)$ (\% vehicles) } \\
\hline & & 0-15 min & $15-30 \mathrm{~min}$ & $30 \mathrm{~min}-1 \mathrm{~h}$ & 1h-5h & $5 h-10 h$ & $10 \mathrm{~h}>$ \\
\hline $7-8$ & 177 & 44.1 & 0.6 & 5.6 & 14.7 & 21.5 & 13.6 \\
\hline 8-9 & 1210 & 47.4 & 6.2 & 2.5 & 11.7 & 26.6 & 5.7 \\
\hline $9-10$ & 821 & 39.0 & 3.3 & 3.7 & 16.3 & 31.8 & 6.0 \\
\hline $10-11$ & 414 & 21.7 & 5.6 & 6.5 & 30.2 & 32.1 & 3.9 \\
\hline 11-12 & 319 & 26.6 & 8.2 & 9.4 & 27.3 & 27.6 & 0.9 \\
\hline $12-13$ & 394 & 27.2 & 5.3 & 7.6 & 41.4 & 18.0 & 0.5 \\
\hline $13-14$ & 465 & 37.4 & 5.6 & 6.5 & 39.8 & 10.8 & --- \\
\hline $14-15$ & 378 & 28.8 & 10.1 & 16.9 & 37.6 & 6.6 & --- \\
\hline $15-16$ & 415 & 38.3 & 18.6 & 13.0 & 26.7 & 3.4 & --- \\
\hline $16-17$ & 393 & 46.1 & 16.5 & 12.5 & 23.2 & 1.8 & --- \\
\hline $17-18$ & 494 & 62.3 & 12.8 & 5.3 & 18.6 & 1.0 & --- \\
\hline $18-19$ & 393 & 63.9 & 9.2 & 5.9 & 19.8 & 1.3 & --- \\
\hline $19-20$ & 212 & 54.7 & 11.8 & 12.7 & 20.8 & --- & --- \\
\hline $20-21$ & 167 & 65.3 & 10.8 & 8.4 & 15.6 & --- & --- \\
\hline $21-22$ & 92 & 60.9 & 12.0 & 19.6 & 7.6 & --- & --- \\
\hline Total & 6344 & 42.8 & 8.4 & 7.3 & 22.9 & 16.1 & 2.6 \\
\hline
\end{tabular}

*: Out of 12194 entries, there were a total 6344 trips with matched entry and exit times.

\section{Conclusions}

Despite the need for traditional survey studies in commute behavior studies, even for campuses, data collected from other systems can be beneficial to understand basics of mobility within the study area, and even in a very cost-effective way. For example, availability of RFID control for all the private car commuters at all the campus entry gates in the METU campus provided the daily travel profile of the campus. Furthermore, detection of a relatively small reverse peak hour brought up the issue of commuting of family members of academic personnel living on campus. The license plate and time stamp in the RFID data made it possible to detect over 6300 trips from approximately 12200 RFID entry records in a day, which makes almost a $50 \%$ sampling rate; this is higher than any sampling ratio aimed in a traditional survey. However, the lack of purpose for the trips identified from RFID data does not enable the identification of all components of commute behaviors clearly and creates some room for speculation.

Furthermore, RFID cardholder type information made it possible to study commuter arrival and departure times of the different campus users, which showed that administrative personnel travel demand is more likely to be served with morning and evening commuter buses, as they have more definite work hours, whereas academic personnel needs more flexible services, if any kind of shared-ride models would be promoted for more sustainable campus transportation. Students on the other hand show a definite delayed arrival and a much longer exit profile, which should be better supported with municipal public transit services to discourage private car usage in this group.

Campus stay time analysis showed that there had been a great number of vehicles stayed on campus less than 15 minutes, which means a transit usage of the campus is high. This may be a good thing in terms of smaller demand for on-campus parking, if it is because of a pick-up/drop-off a campus user. But, smaller rates of longer stays (up to 4 or 8 hours) show that the current congestion on campus parking lots is due to the almost must private car usage to access to/within the campus, which can be improved by addressing campus commute needs of both students and personnel in a broader perspective.

In the longer run, RFID data can be collected over a long period of time, such as an academic semester, using which differences across weekdays, or the effects of weather condition on commute behavior can be evaluated which may be the focus of future studies. Furthermore, the travel behavior of each individual commute traveler can be followed over a long time which provides to build more comprehensive campus transportation model for different commute travelers. Finally, installing the RFID system to all parking lots in METU campus enables to analyze the time dependent parking lot capacity analysis, to analyze campus travel time analysis and to develop parking management policies for METU campus, which can be also considered in future studies.

\section{References}

[1] Zhou J. "Sustainable commute in a car-dominant city: factors affecting alternative mode choices among university students". Transportation Research Part A, 46(7), 1013-1029, 2012.

[2] Miralles-Guasch C, Domene E. "Sustainable transport challenges in a Suburban University: The case of the autonomous university of Barcelona". Transport Policy, 17(6), 454-463, 2010.

[3] Akar G, Flynn C, Namgung M. "Travel choices and links to transportation demand management: Case study at Ohio State University". Journal of the Transportation Research Board, 2319, 77-85, 2012. 
[4] Limanond T, Butsingkorn T, Chermkhunthod C. "Travel behavior of university students who live on campus: A case study of a Rural University in Asia". Transport Policy, 18(1), 163-171, 2011.

[5] Gilhooly P, Low DJ. "Primary school travel behavior in Midlothian, UK". Institution of Civil Engineers-Municipal Engineer, 158(2), 129-136, 2005.

[6] Huayan S, Wenji L, Haijun H. "Empirical study of parking problem on university campus". Journal of Transportation Systems Engineering and Information Technology, 7(2), 135-140, 2007.

[7] Knowledge Arabia. "RFID Car Parking Solutions". http://kateck.com/node/49 (20.01.2015).

[8] The University of Arizona. "Parking and Transportation Services". https://parking.arizona.edu/permits/rfid.php (20.01.2015).
[9] Wayne State University. "Parking and Transportation Services". http://parking.wayne.edu/students/assigned.php (20.01.2015).

[10] University of Wisconsin. "Campus Transportation Committee Annual Report 2008-2009". Madison, USA, 2213, 2010.

[11] Oregon Department of Transportation. "Multimodal Transportation Program Project Application". www.ocwcog.org/Files/Harrisburg\%20Application.pdf (20.01.2015).

[12] Altintasi 0. Assessment of Scenarios for Sustainable Transportation at METU Campus. MSc Thesis, Middle East Technical University, Ankara, Turkey, 2013. 